\title{
Correction to: Do translocal networks matter for agricultural innovation? A case study on advice sharing in small-scale farming communities in Northeast Thailand
}

\author{
Till Rockenbauch ${ }^{1}\left[\right.$ Patrick Sakdapolrak ${ }^{2}\left[\right.$ Parald Sterly $^{2}(\mathbb{C}$
}

Published online: 28 August 2019

(c) The Author(s) 2019

\section{Correction to: Agriculture and Human Values https://doi.org/10.1007/s10460-019-09935-0}

The article "Do translocal networks matter for agricultural innovation? A case study on advice sharing in small scale farming communities in Northeast Thailand", written by Till Rockenbauch, Patrick Sakdapolrak and Harald Sterly, was originally published electronically on the publisher's internet portal (currently SpringerLink) on 10 April 2019 without open access.

The copyright of the article changed on August 2019 to (c) The Author(s) 2019 and the article is forthwith distributed under the terms of the Creative Commons Attribution 4.0 International License (http://creativecommons.org/licen ses/by/4.0/), which permits use, duplication, adaptation, distribution and reproduction in any medium or format, as long as you give appropriate credit to the original author(s) and the source, provide a link to the Creative Commons license and indicate if changes were made

Open Access This article is distributed under the terms of the Creative Commons Attribution 4.0 International License (http://creativecommons.org/licenses/by/4.0/), which permits unrestricted use, distribution, and reproduction in any medium, provided you give appropriate credit to the original author(s) and the source, provide a link to the Creative Commons license, and indicate if changes were made.

Publisher's Note Springer Nature remains neutral with regard to jurisdictional claims in published maps and institutional affiliations.
The original article can be found online at https://doi.org/10.1007/ s10460-019-09935-0.

Till Rockenbauch

till.rockenbauch@uni-bonn.de

Patrick Sakdapolrak

patrick.sakdapolrak@univie.ac.at

Harald Sterly

harald.sterly@univie.ac.at

1 Department of Geography, University of Bonn, Meckenheimer Allee 166, 53115 Bonn, North Rhine-Westphalia, Germany

2 Department of Geography and Regional Research, University of Vienna, Universitätsstraße 7/5, 1010 Vienna, Austria 